\title{
Studies on design evaluation of Product Packaging availability Based on Analysis of Eye Movements
}

\author{
Pang Yeying \\ (Hunan University of Technology, Zhuzhou, Hunan, R.P. China, Zip Code 412000) \\ E-mail: 565491781@qq.com
}

\begin{abstract}
The thesis designed eye movement experiment based on the packaging case of PINO tissue. It made eye movement evaluation on the packaging availability of PINO by packaging open experiment, eye movement experiment and analysis. It clarified the advantage and limitation of product packaging on the basis of analyzing the test result. In the design of product packaging, high purified color scheme will be more attractive to young consumers. Meanwhile, the key for PINO accomplishing such outstanding achievement arises from its vivid color and novel outlook. There are also some inconvenient problems on the processing of packaging opening. The analysis and assessment provide reliable experimental data for optimizing the product packaging in the future.
\end{abstract}

Key words: eye movement; product packaging; availability; design evaluation

In modern product packaging design, as marginal effect gradually diminishes, consumers' needs and feelings are being taken highly attention. With product function gradually perfect, the contradiction between product function complication and practice simplicity is deepening which leads to the problem of product packaging availability. Nilesen(1993) and Hartson(1998) put forward the concept of user interface availability, but they did not make further analysis on definition's operability. '1】 Damasio A R, famous psychologist in America, put forth the design principle of availability by further study on the relation between consumer's psychology and availability design in daily product and successfully assisted the corporation to

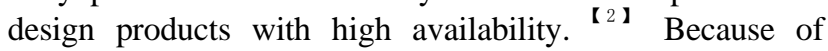
consumer base's difference, packaging nature and product feature determine the design connotation with availability should be involved in product packaging. Under the condition of product protection, storage, transportation and sales going well, availability design of product packaging highlights the function of packaging design and promotes utility value in aesthetics, economy, environment, uniqueness, social and culture for meeting consumer's subjective and objective emotion needs by packaging design in style, construction, material, decoration, process etc.

Eye movement evaluation towards product packaging availability design evaluates consumer's psychology and behavior by tracing subjects' eye movement track so that can get one qualitative and objective result. Through eye movement tracing, we can get the first fixation, fixation arrangement, fixation duration and fixation sequence from consumers' feedback towards product packaging and product shelf's setting so that can make further research on consumers' behavior which . ${ }^{\mathbf{3} \mathbf{1}}$ to a great extent, can affect and even determine the brand's competiveness and benefit.

This study is mainly based on PINO tissue and market analysis which get from market survey and questionnaire. It analyzes the product packaging availability and evaluates the phases in eye movement experiment such as packaging opening, feedback on using and eye movement test etc. Furthermore, the study analyzes and evaluates the advantages and limitation of tested products so that it can provide reliable experimental data for optimizing design of product packaging in future.

\section{RESEARCH METHOD}

\section{A. Experimental Facilities}

The experiment was done with new generation Sweden Tobii T60 eye tracker. Its 17-inch LCD is applicable for revealing stimulus material by viewing screen. By Tobii eye movement tracing, it can inspect the subjects' thinking conveniently and precisely as well as further insight the human's behavior without the interference from other apparatus.

\section{B. Subjects}

The experiment included 30 undergraduates, aged 20 to 28 years. Among those subjects, there were 12 males and 18 females who used congeneric product no less than 3 times a day.

\section{Experimental Material}

PINO tissue was selected as the main research product while three other congeneric products were selected to do packaging contrast experiment. For lowering the influence of PINO tissue's visual elements on its color elements such as color and texture, all the pictures have been modified by photoshop. Four tissue packaging were put together in the same pictures as the experimental material. Subjects chose its favorite packaging. Besides, all picture's background were set to white and its central position was hollowed so as to eliminate the interference of position element. All products were with the same size, light and dark, perspective and contrast.

\section{Experimental Procedure}

1) Main research product was put together with congeneric products in the same photo to do packaging contrast. Subjects chose one favorite product. The experiment tested eye movement attention trace, fixation duration, first fixation and generated heat map and interest fixation map. Heat map, which is an image generated by statistics on the basis of subjects' eye movement data, 
reflects the overall condition of fixation and sight movement on the screen. Different heat maps are drawn by different eye tracking softwares which cope with the pictures, webpages even the data from videos of testing activity.

2) Subjects watched the PINO tissue's packaging. Subjects' watching sequence was: front view-side view-top view. The experiment tested eye movement attention trace, fixation duration, first fixation and generated heat map and interest fixation map.

\section{EXPERIMENTAL ANALYSIS}

\section{A. Packaging Opening Test}

Packaging opening test included 28 subjects who were divided into 5 groups. Each group included 5 or 6 people. To open the first layer of plastic transparent packaging, it took these 5 groups of subjects 10 seconds, 10 seconds, 22 seconds, 21 seconds, 18 seconds respectively and the average time is 16 seconds. To open the second layer of packaging, they spent 11 seconds, 11 seconds, 5 seconds, 12 seconds, 14 seconds respectively and the average time is 3 seconds. To take out the product by opening packaging, it took 2 seconds, 2 seconds, 2 seconds, 6 seconds, 5 seconds respectively and the average time is 3 seconds. The plastic packaging was damaged seriously when these 5 groups of subjects opened the first layer of plastics transparent packaging. Thus, they suggested that an easy-to-pull opening should be affixed in the first layer of packaging. There were 2 groups thought tissue's opening mark was not obvious and should be improved. Results of analysis, which is based on the panel discussion after packaging opening test, point to the conclusion that: at first sight, $14.2 \%$ consumers have comparative weak desire to buy, $42.8 \%$ consumers have the desire to buy, $7.1 \%$ consumers have strong desire to buy. Results of analysis on the basis of data pointed that, consumers have deep first impression towards this product; in the process of opening, $50 \%$ consumers think this product is convenient for using; 82\% consumers satisfied with packaging's protective effect; only 3.5\% consumers think such product packaging with low protective effect. In overall satisfaction of this packaging, nobody is unsatisfied and more than $50 \%$ consumers have high or even very high satisfaction level towards this product packaging.

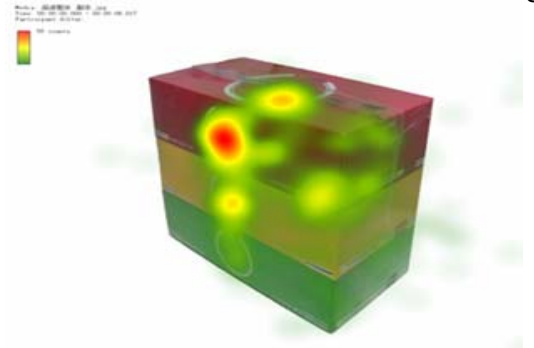

Figure 1 Heat Map of PINO Tissue’s Overall Packaging

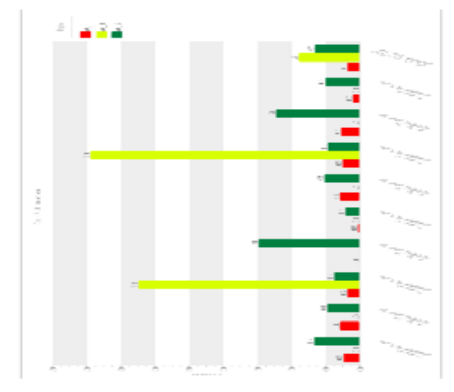

Figure 2 Time to First Fixation Figure of PINO Tissue’s Overall Packaging

B. Contrast Experiment between PINO Tissue and Other Tissues

The experiment made contrast between PINO Tissue and other congeneric products by below key points: first fixation duration, time to first fixation, total fixation duration. It made the systematic analysis after selecting experimental field.

First fixation duration is the looking time on the first fixation in some interest area which shows how many times subjects look at the products in the process of experiment. '51 Besides, it presents how much attention the products get. Generally, the product with contents, complicacy and novelty is easy to raise the attention. While the more attention, the better.

PINO tissue was divided into the second interest area as figure I shows. Regarding the summarizing column of stimulus materials in AOI, $\mathrm{N}$ presents how many interest areas were recorded under one stimulus element; Mean presents average value; sum presents the summation of interest areas. We can find out that in the second interest area, the value of $\mathrm{N}$ was 44 , the value of $\mathrm{M}$ was 0.34 and the value of $\mathrm{S}$ was 15.11 which all exceeded the values in other interest areas. Thus, PINO tissue won in the first fixation duration.

Table 1 PINO Tissue’s First Fixation Duration on Comparison Packaging

\begin{tabular}{|c|c|c|c|c|c|}
\hline \multicolumn{6}{|c|}{$\begin{array}{c}\text { Tissue Experiment ( Detailed Graph of the First Fixation } \\
\text { Duration ) }\end{array}$} \\
\hline \multicolumn{3}{|c|}{ Region of Interest I } & \multicolumn{3}{|c|}{ Region of Interest II } \\
\hline $\begin{array}{c}\mathrm{N} \\
\text { Count }\end{array}$ & $\begin{array}{c}\text { Mean } \\
\text { Seconds }\end{array}$ & $\begin{array}{c}\text { Sum } \\
\text { Seconds }\end{array}$ & $\begin{array}{c}\mathrm{N} \\
\text { Count }\end{array}$ & $\begin{array}{c}\text { Mean } \\
\text { Seconds }\end{array}$ & $\begin{array}{c}\text { Sum } \\
\text { Seconds }\end{array}$ \\
\hline 41 & 0.28 & 11.31 & 44 & 0.34 & 15.11 \\
\hline \multicolumn{3}{|c|}{ Region of Interest III } & \multicolumn{3}{|c|}{ Region of Interest IV } \\
\hline $\begin{array}{c}\mathrm{N} \\
\text { Count }\end{array}$ & $\begin{array}{c}\text { Mean } \\
\text { Seconds }\end{array}$ & $\begin{array}{c}\text { Sum } \\
\text { Seconds }\end{array}$ & $\begin{array}{c}\mathrm{N} \\
\text { Count }\end{array}$ & $\begin{array}{c}\text { Mean } \\
\text { Seconds }\end{array}$ & $\begin{array}{c}\text { Sum } \\
\text { Seconds }\end{array}$ \\
\hline 44 & 0.33 & 14.41 & 44 & 0.32 & 14.15 \\
\hline
\end{tabular}

C. Experiment of PINO Tissue's Overall Effect ( take Figure 1 as an example) 
Table 2 Time to First Fixation Test Result of PINO Tissue’s Overall Packaging

\begin{tabular}{|c|c|c|c|c|c|}
\hline \multicolumn{6}{|c|}{$\begin{array}{c}\text { Time to First Fixation Test of PINO Tissue's Overall } \\
\text { Packaging }\end{array}$} \\
\hline \multicolumn{3}{|c|}{ Region of Interest I } & \multicolumn{3}{|c|}{ Region of Interest II } \\
\hline $\mathrm{N}$ & Mean & Sum & $\mathrm{N}$ & Mean & Sum \\
\hline Count & Seconds & Seconds & Count & Seconds & Seconds \\
\hline 44 & 0.65 & 28.59 & 39 & 1.44 & 56.24 \\
\hline \multicolumn{3}{|c|}{ Region of Interest III } & & & \\
\hline $\mathrm{N}$ & Mean & Sum & & & \\
\hline Count & Seconds & Seconds & & & \\
\hline 35 & 0.96 & 33.74 & & & \\
\hline
\end{tabular}

Table 3 Total Fixation Duration Test of PINO Tissue's Overall Packaging

\begin{tabular}{|c|c|c|c|c|c|}
\hline \multicolumn{6}{|c|}{$\begin{array}{c}\text { Time to First Fixation Test of PINO Tissue's Overall } \\
\text { Packaging }\end{array}$} \\
\hline \multicolumn{3}{|c|}{ Region of Interest I } & \multicolumn{3}{|c|}{ Region of Interest II } \\
\hline $\begin{array}{c}\mathrm{N} \\
\text { Count }\end{array}$ & $\begin{array}{c}\text { Mean } \\
\text { Seconds }\end{array}$ & $\begin{array}{c}\text { Sum } \\
\text { Seconds }\end{array}$ & $\begin{array}{c}\mathrm{N} \\
\text { Count }\end{array}$ & $\begin{array}{c}\text { Mean } \\
\text { Seconds }\end{array}$ & $\begin{array}{c}\text { Sum } \\
\text { Seconds }\end{array}$ \\
\hline 44 & 2.25 & 98.82 & 39 & 0.94 & 36.56 \\
\hline \multicolumn{3}{|c|}{ Region of Interest III } & & & \\
\hline $\begin{array}{c}\mathrm{N} \\
\text { Count }\end{array}$ & $\begin{array}{c}\text { Mean } \\
\text { Seconds }\end{array}$ & $\begin{array}{c}\text { Sum } \\
\text { Seconds }\end{array}$ & & & \\
\hline 35 & 0.83 & 28.96 & & & \\
\hline
\end{tabular}

In this experiment, the first interest area was front face, the second area was top face, the third area was side face. From the data in Table 2, the average value of entering the first area is 0.65 seconds which is the shortest; however, the summation of fixation duration is 2.25 seconds. In the histogram analysis of time to first fixation, RED presents the first interest area (front face) of "PINO tissue", GREEN presents the second interest area of "PINO tissue (top face)", YELLOW presents the third interest area (side face). The analysis is based on the test result of 10 subjects with more than $90 \%$ validity in the histogram. It was clearly shown that the entry time of text was higher than the images. That is to say, front side was drawn highest attention in the overall packaging. So, more effective information should be arranged in the front side for consumer to identify and memorize. In the product display, the entry time of side face was fast so that side face is also indispensable face for information transfer. Thus, secondary information should be arranged in side face. Although, the duration in top area is 0.11 second more than side face, the entry time is longer. It is suggest that the information transfer should not be arranged in top face.

\section{CONCLUSION}

The study made eye movement evaluation on the packaging availability of PINO tissue by packaging open experiment, eye movement test and analysis. It clarifies the advantage and limitation of product packaging on the basis of analyzing the test result. The test result pointed that high purified color scheme will draw consumer's attention easily and bright color scheme will be more attractive for young consumers. Meanwhile, the key for PINO accomplishing such outstanding achievement arises from its vivid colour and novel outlook. However, there are still some problems in the way of opening the packaging. It took relatively longer time to open the fist layer of packaging which does not convenient and have to destroy the packaging to open.

\section{ACKNOWLEDGMENT}

Fund Programme: the phased objectives of psychology social science fund programme "Studies on Product Availability Design Based on Eye Movement Analysis"

( Approval NO.: 12YBB076).

Author: Pang Yeying (1970-), female, was born in Shaoshan, Hunan province. The author, with master's degree, is an instructor in Technology Institute of Hunan University of Technology. Direction of research is theory and culture of modern design.

\section{REFERENCE}

[1] Damasio A R. Descartes' Error: Emotion, Reason and the Human Brain. New York: Putnam, 1994: 55.

[2]Dorman D A. The Design of Everyday Thing.New York:Doubleday Dell Publishing Grouug.

1990:Preface,82.

[3] Yan Guoli. The Application of Eye Movement Analytical Method in Psychological Research [M]. Tian Jin: Tian Jin Education press. 2004: 134.

[4] Mark C.Russell.HotsPots and Herlinks : Using Eye-tracking to SuPPlement Usability Testing [EB/OL].

[5] Xiong Jianpin, He Miao. Eye Movement Study on Aesthetics Preference in Ming Dynasty and Qing Dynasty [J]. Application Study, 2010(09):116. 